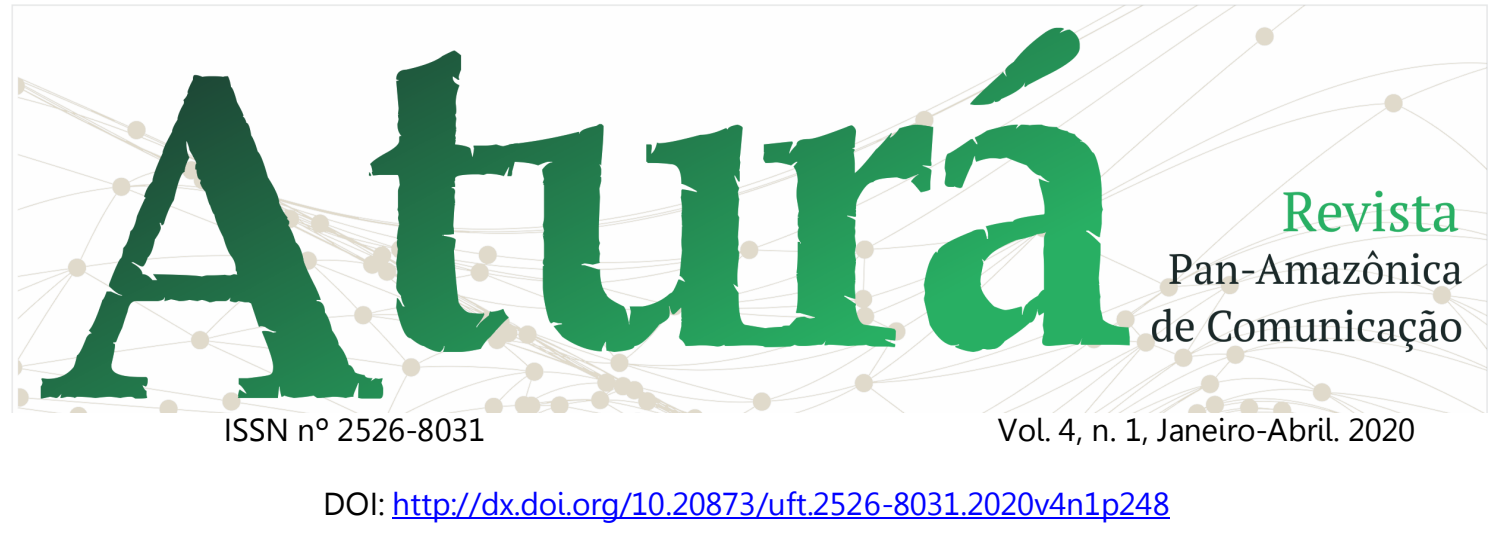

\title{
A COBERTURA JORNALÍSTICA DA AIDS/HIV NO JORNAL FOLHA DE BOA VISTA ENTRE OS ANOS DE 1993 E 2001
}

\author{
JOURNALISTIC COVERAGE OF AIDS / HIV IN THE FOLHA DE BOA VISTA NEWSPAPER \\ BETWEEN 1993 AND 2001
}

COBERTURA PERIODÍSTICA DEL SIDA / VIH EN EL PERIÓDICO FOLHA DE BOA VISTA ENTRE 1993 Y 2001

\section{Jackson de Souza Félix ${ }^{1}$ Vilso Junior Santi²}

\section{RESUMO}

Este trabalho pretende mostrar qual foi papel da mídia impressa roraimense no contexto da epidemia do HIV/Aids, no final do século XX, a fim de compreender quais as mensagens foram veiculadas sobre o tema no jornal impresso Folha de Boa Vista, entre os anos de 1993 a 2001. Para isso foi utilizada como estratégia teórico-metodológica os preceitos da teoria do agendamento e dos critérios de noticiabilidade, tratados através de indicadores quantitativos e qualitativos. Foi realizada também uma breve discussão sobre a relação entre jornalismo e saúde a fim de compreender melhor essa interface, bem como a forma de veiculação de notícias sobre a Aids. Apesar de passar por diferentes fases ao longo dos últimos 30 anos, a pauta sobre este tema ainda é pertinente e merece atenção.Com base nisso, esta produção vem propor a discussão de como fazer um jornalismo de forma humanizada e imparcial, no que tange ao preconceito, para que a sociedade se conscientize sobre a ocorrência da doença.

PALAVRAS-CHAVE: HIV/Aids; Jornalismo Especializado; Cobertura Jornalística; Saúde; Roraima.

\footnotetext{
1 Graduado em Comunicação Social - Jornalismo pela Universidade Federal de Roraima. E-mail: jacksonsoufe@outlook.com.

2 Professor do Curso de Comunicação Social - Jornalismo da UFRR. E-mail: vjrsanti@gmail.com.
} 


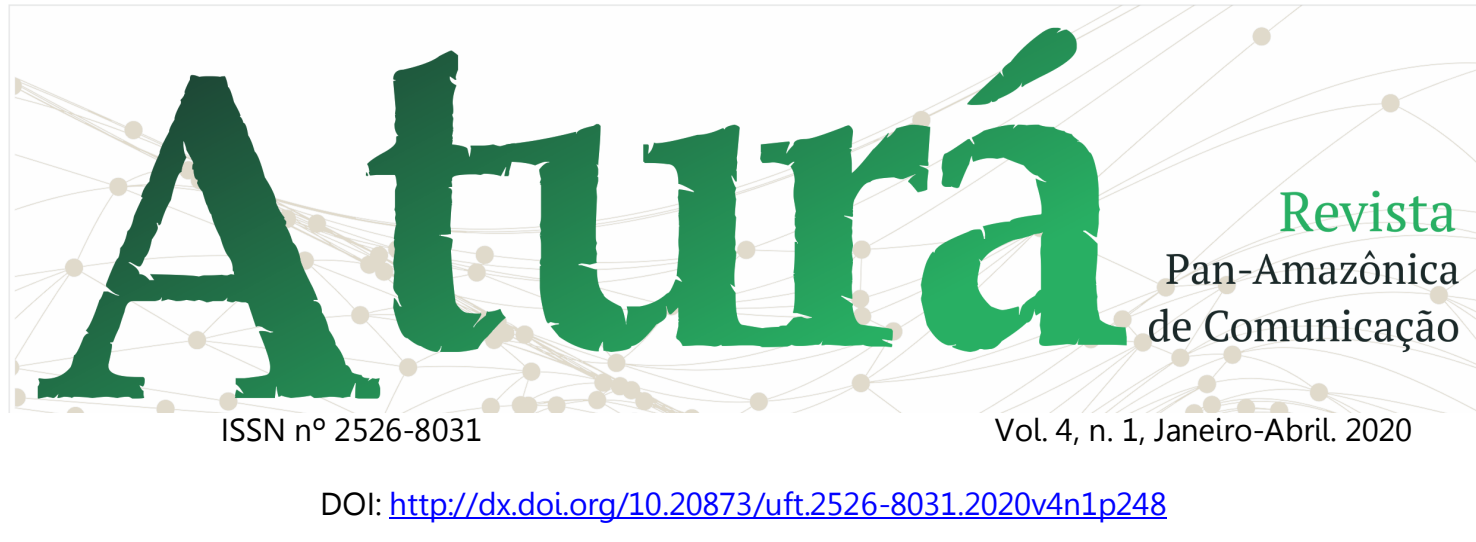

\begin{abstract}
This work intends to show what was the role of the press in Roraima in the context of the HIV / AIDS epidemic, at the end of the 20th century, in order to understand what messages were conveyed on the topic in the printed newspaper Folha de Boa Vista, between the years of 1993 to 2001. For this purpose, the precepts of scheduling theory and news criteria were used as a theoreticalmethodological strategy, treated through quantitative and qualitative indicators. There was also a brief discussion on the relationship between journalism and health in order to better understand this interface, as well as the way of spreading news about AIDS. Despite going through different phases over the last 30 years, the agenda on this topic is still relevant and deserves attention. Based on this, this production proposes the discussion of how to do journalism in a humane and impartial way, with regard to the prejudice, so that society becomes aware of the occurrence of the disease.
\end{abstract}

KEYWORDS: HIV / AIDS; Specialized Journalism; News coverage; Cheers; Roraima.

\title{
RESUMEN
}

Este trabajo pretende mostrar cuál fue el papel de la prensa en Roraima en el contexto de la epidemia del VIH / SIDA, a fines del siglo XX, para comprender qué mensajes se transmitieron sobre el tema en el periódico impreso Folha de Boa Vista, entre los años de 1993 a 2001. Para este propósito, los preceptos de la teoría de programación y los criterios de noticias se utilizaron como una estrategia teórico-metodológica, tratada a través de indicadores cuantitativos y cualitativos. También hubo una breve discusión sobre la relación entre periodismo y salud para comprender mejor esta interfaz, así como la forma de difundir noticias sobre el SIDA. A pesar de haber pasado por diferentes fases durante los últimos 30 años, la agenda sobre este tema sigue siendo relevante y merece atención. En base a esto, esta producción propone la discusión sobre cómo hacer periodismo de una manera humana e imparcial, con respecto al prejuicio, para que la sociedad tome conciencia de la aparición de la enfermedad.

PALABRAS CLAVE: VIH / SIDA; Periodismo especializado; Cobertura de noticias; Salud; Roraima.

Recebido em: 19.11.2019. Aceito em: 12.12.2019. Publicado em: 03.01.2020. 


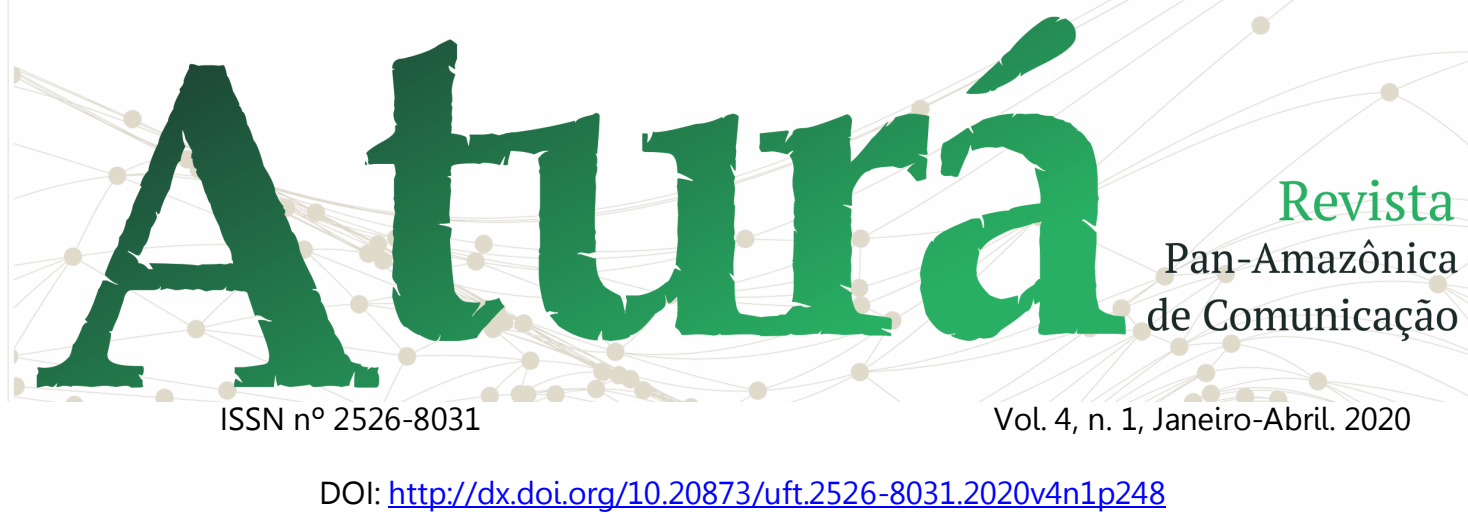

\section{Introdução}

Para compreender o HIV/Aids dentro do meio jornalístico se faz necessário entender a relação entre a comunicação e a saúde, que segundo Defoe (1985), esta relação é bastante antiga. Em uma de suas obras ele narra sobre a peste bubônica, pandemia mais conhecida como Peste Negra, quando dizimou 1/4 da população europeia em 1347 e permaneceu atuando do século XIV até o século XVII.

Se comparado às últimas décadas do século $X X$, podemos dizer a Aids tomou e tem tomado a mesma proporção que Peste Negra durante a Idade Média, mas ao contrário do que ocorre com hoje com os meios de comunicação, antes as informações sobre a doença eram dadas através da igreja, instituição política e religiosa que dominava o pensamento da época.

Já no século XXI, Lopes et al. (2011) afirma que a comunicação em saúde cresceu como uma forma de resposta aos interesses holísticos e pragmáticos da promoção de saúde e da prevenção de doenças, se transformando numa área de convergência e de colaboração entre as duas áreas.
Na área da saúde, as autoras afirmam que a objetividade da informação pode encontrar alguns obstáculos, principalmente no acesso às fontes, que por muitos profissionais é descrito como difícil. "[...] Encontrar fontes que estejam dispostas a falar com os jornalistas e a contarem as suas 'estórias' parece constituir uma tarefa árdua" (LOPES et al, 2011, p.103).

Elas afirmam também, que em geral, as fontes de informação solicitadas para falar na matéria deste gênero, são múltiplas, são elas: oficiais, especializadas institucionais, fontes especializadas não institucionais, cidadão comum, entre outras.

Além disso, os profissionais da saúde encontram na mídia um meio de difusão de informação e criação de sentido, de diferentes formas, quer seja informativo, educacional, ou até persuasivo, com o objetivo de promover a compreensão aos assuntos relacionados à saúde. Nesse sentido:

[...] as fontes governamentais ou organizações prestadoras de saúde (ditas 'fontes oficiais') tendem a ser colocadas na primeira linha dos contatos. Trata-se de fontes abertas e confiáveis. A sua informação é clara e condensada. E são 


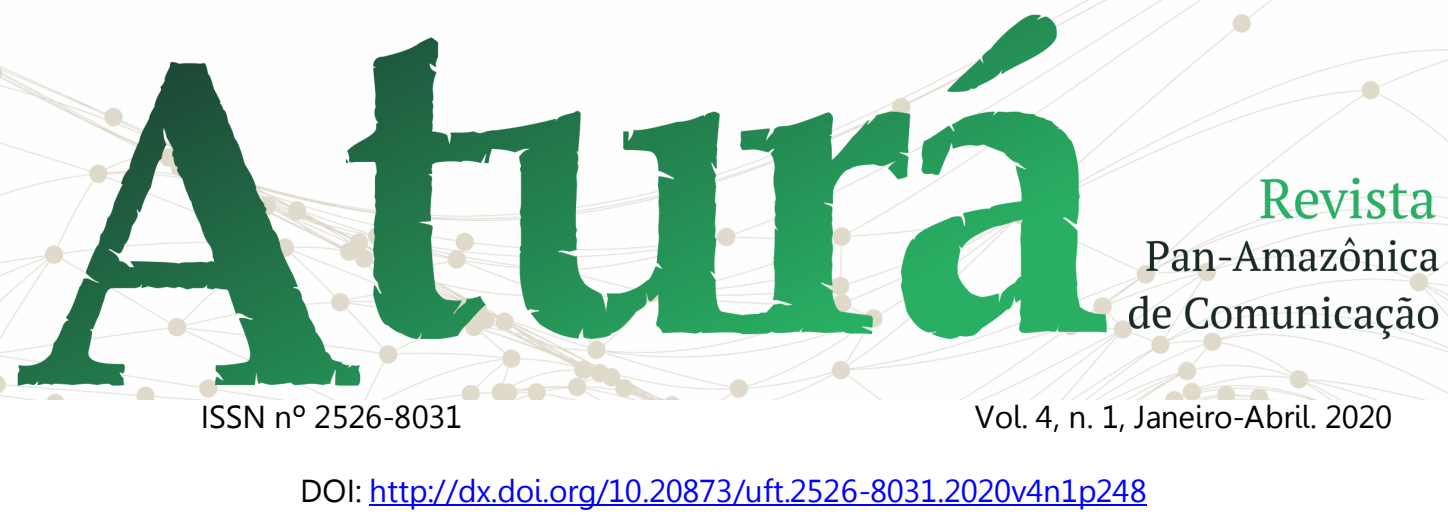

proativas na comunicação das suas 'estórias'. Além do mais, ao apresentarem posições formais, estas fontes criam uma 'esfera de consenso', que parece 'libertar' o jornalista da necessidade de aceder a vozes alternativas (LOPES et al, 2011, p.104).

Conforme Lopes et al (2011, p.105), um estudo realizado em 2008, centrado nos meios de comunicação norte-americanos, colocava as notícias sobre saúde no sexto lugar das preferências do público. Entre os fatores deste crescimento, as autoras destacaram o relacionamento a disponibilidade dos profissionais da saúde face às solicitações dos jornalistas; e ao reforço das atividades de marketing e promovidas pela assessoria de imprensa.

Com base nestas informações, a veiculação dos mais variados tipos de informações através dos meios de comunicação de massa passou a ser reconhecida como importante fator auxiliar na divulgação sobre assuntos relacionados à saúde, o que consequentemente fortalece ações preventivas no campo da saúde pública.

Além disso, a veiculação de matérias sobre este tema só são possíveis quando a imprensa agenda as pautas e desenvolve uma linguagem própria à divulgação de saúde, o que não acontece para a maior parte dos noticiários.

A partir de uma visão macro da situação, vemos, conforme Macedo et al. (2013), que apesar de o espaço dedicado à saúde ser relativamente extenso na mídia, os textos frequentemente são muito formais ou teóricos, raramente apelando para o humor e para a análise de experiências concretas o que prejudica a circulação destas informações entre a população.

Teoria do agendamento e critérios de noticiabilidade

O jornalista como um agente formador do pensamento crítico precisa ter a consciência de selecionar os fatos que serão ou não notícias dentro do veículo de comunicação em que ele trabalha, para que dessa forma as pessoas tenham acesso à informação aos temas que elas mesmas elegem como pertinentes, atuando dessa forma como gatekeeper, da forma como 


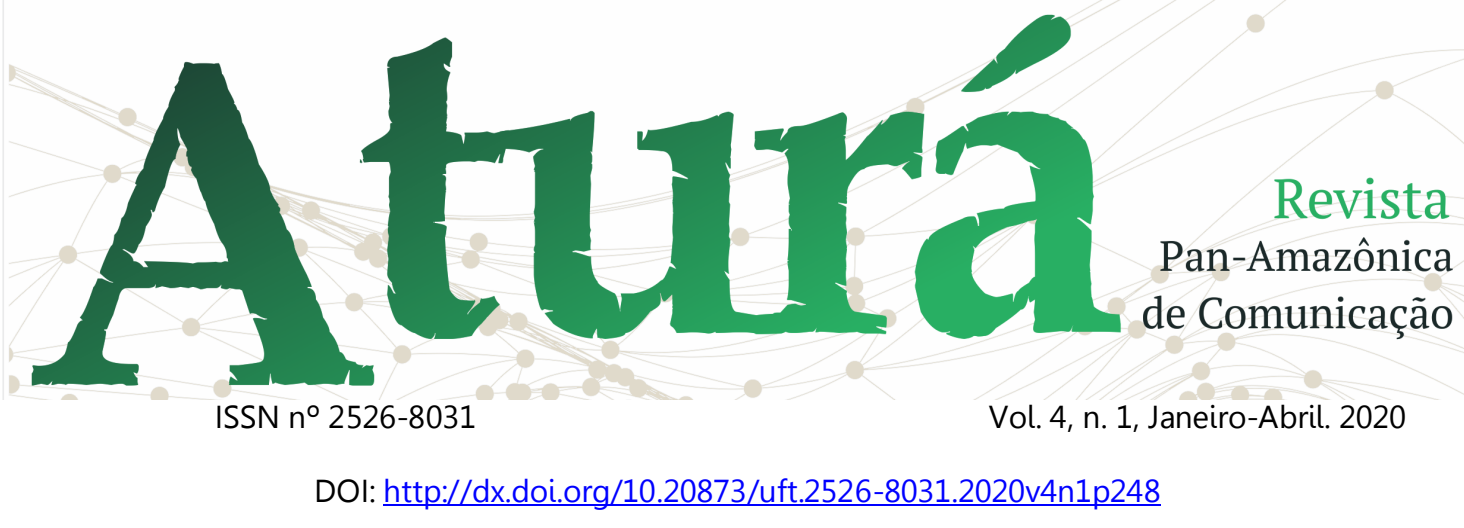

defende Mattelart (2009, p.56). Ou seja, é ele o "controlador do fluxo de informação, função que o garante como 'formador de opinião".

Tomamos como base o estudo da Teoria do Agendamento e dos Critérios de Noticiabilidade (ou Valores Notícia), para melhor exemplificar a partir de que ponto um fato pode se tornar notícia e discutir quais em critérios a Aids se encaixa - neste caso tomada como uma patologia, um fato a ponto se tornar notícia (TRAQUINA, 2001; SILVA 2009).

O processo de produção da notícia tem como base a seleção dos fatos que são elencados de acordo como os critérios de noticiabilidade, que segundo Silva (2009. p.97) são a "soma do conjunto de elementos por meio dos quais a empresa jornalística controla e administra a quantidade e o tipo de acontecimentos", bem como o conjunto de elementos intrínsecos que demonstram a aptidão ou potencial de um evento para ser transformado em notícia.

Para Traquina (2001), apud Silva (2005), "notícias são o resultado de um processo de produção definido como a percepção, a seleção e a transformação de uma matéria- prima (principalmente os acontecimentos) num produto".

Já Silva (2005) defende que os critérios de noticiabilidade nascem da constatação prática da falta de espaço nos veículos de comunicação para a publicação ou veiculação dos mais variados de acontecimentos que ocorrem no cotidiano.

Com base nestas informações, podemos dizer que a transformação da Aids em notícia está relacionada à alguns critérios, na sua maioria elencados por Lippman, conforme citado por Silva (2005). Entre eles, podemos nomear o interesse universal, no qual um fato está ligado às consequências globais e ao mesmo tempo ao seu impacto na sociedade. Outro critério de noticiabilidade mobilizado é o número de pessoas afetadas ou a amplitude, tendo em vista que a doença atingiu e ainda atinge uma grande quantidade de indivíduos. O HIV/Aids também está relacionado diretamente ao negativismo, uma vez que a primeira impressão acerca da enfermidade é o risco de morte.

Também podemos dizer que com o surgimento da Aids, a curiosidade foi utilizada 


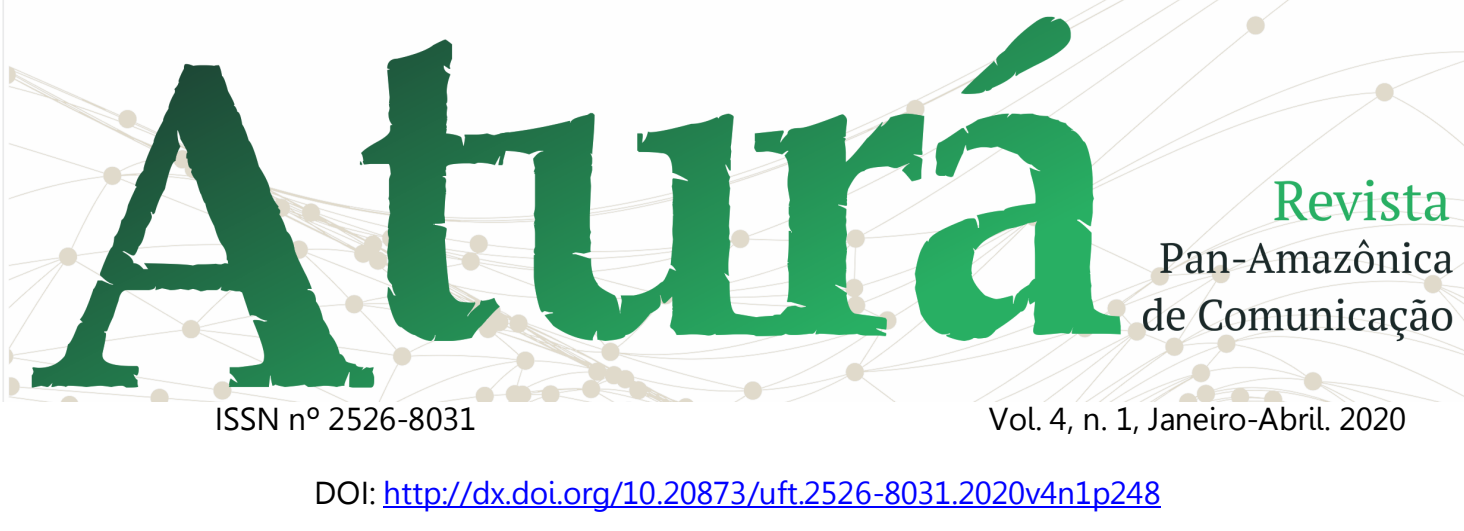

como um critério e é usada ainda hoje, tendo em vista que a doença continua uma incógnita para a ciência. Do ponto de vista jornalístico, o desconhecido atrai os interesses dos meios de comunicação que buscam a qualquer custo desvendar ou mostrar uma solução sobre determinado tema.

Três décadas após seu aparecimento, a pandemia ainda é muito atual, fator este que é utilizado pelo jornalismo como valor notícia. Outra característica também utilizada pelas redações é a proeminência social, quando pessoas de notoriedade, celebridades ou posição hierárquica são afetadas pela enfermidade - como ocorreu com os músicos Cazuza e Renato Russo e com o ator Lauro Corona.

\section{O Jornal Folha de Boa Vista}

Nesta pesquisa foram analisadas as matérias publicadas pelo jornal Folha de Boa Vista - criado há quase 34 anos. O jornal é o veículo impresso que se mantém há mais tempo em circulação no Estado de Roraima. Conforme Morais (2005), também entre os anos de 1993 e 2001, recorte temporal desta pesquisa, a Folha de Boa Vista era o principal veículo de informação impressa do Estado.

A coleta de dados foi realizada no período de 18 de outubro e 16 de novembro, por meio da pesquisa na seção de periódicos do Núcleo de Documentação Histórica da Universidade Federal de Roraima (UFRR). Foram coletadas um total de 18 matérias jornalísticas do gênero informativo, entre notícias e reportagens, que tematizavam a questão da Aids/ HIV no período.

O recorte da pesquisa ficou prejudicado pela ausência de material disponível, tendo em vista que o agendamento sobre o tema mantinha um intervalo de em média dois anos até que outra notícia sobre a epidemia fosse publicada. Tal fato explica a coleta de apenas 18 matérias no período de sete anos. Isso representa uma média de duas notícias sobre Aids/ HIV, por ano, no período analisado média considerada relativamente baixa, para assunto de tamanha pertinência.

Além do nosso objeto de estudo, foi possível encontrar notícias sobre o tema no jornal concorrente da época - o Estado de Roraima (pertencente ao Senador Romero 


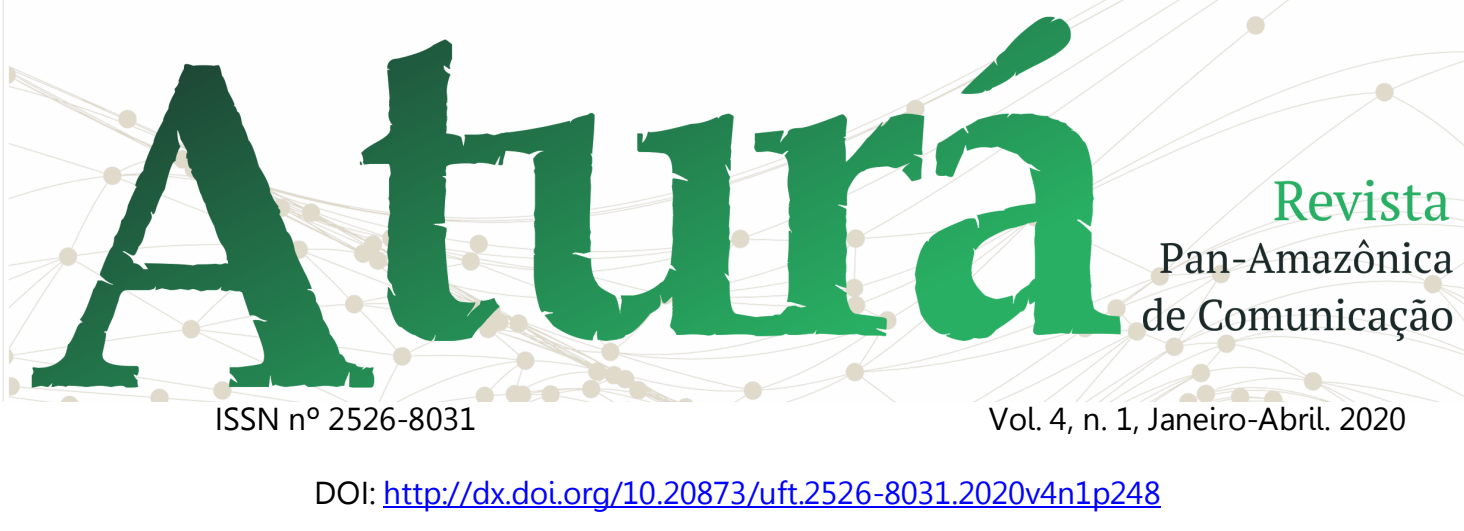

Jucá conforme informações da pesquisa conduzida por Silva e Vieira (2010)). A notícia mais antiga selecionada no corpus de análise data de 24 de dezembro de 1985, publicada em outro jornal "O Roraima". As demais correspondem aos anos de 1989 e 1991 notícias e notas informativas presentes no Jornal Estado de Roraima.

A análise do material teve início a partir de uma edição do Jornal Folha de Boa Vista publicada em 1989, mas como não foi encontrada nenhuma notícia sobre o tema pesquisado, partimos para a próxima edição disponível no acervo documental. Foram encontradas matérias somente a partir da década de 1990.

No ano de 1993 foram publicadas duas matérias sobre Aids/ HIV na Folha de Boa Vista, ambas destacadas na primeira página do jornal. Uma matéria foi publicada no dia 27 e outra no dia 28 de julho. Apesar da proximidade temporal, elas tratavam de assuntos diferentes.

Sem matérias publicadas nos anos de 1994 e 1995 saltamos para 1996. Neste ano a Folha reproduziu oito matérias sobre 0
HIV/Aids. Metade delas foram publicadas na primeira página, enquanto a outra metade recebeu atenção um pouco menor.

Dois anos depois, em 1998, o veículo publica cinco notícias relacionadas ao tema. Três delas sem destaque na página principal do jornal. Em 1999 não houve nenhum registro sobre doença, mas no ano seguinte, em 2000, é publicada uma matéria. Já na virada do século, a Folha de Boa Vista divulga duas notícia sobre o tema, uma delas com destaque na primeira página.

Além das notícias e reportagens o jornal publicou ainda duas notas relacionadas à Aids na Coluna Social - uma em 1993 e outra em 1996. A maior parte dos itens veiculados pela Folha de Boa Vista foi encontrada dentro do Primeiro Caderno, na Editoria Cidades.

\section{Análise do material}

Os itens pontuados a seguir são fruto do trabalho de análise do material coletado. Nele evidencia-se alguns elementos jornalísticos como título, data de publicação e editoria. A partir dessa organização (Tabela 1) podemos fazer algumas observações. 


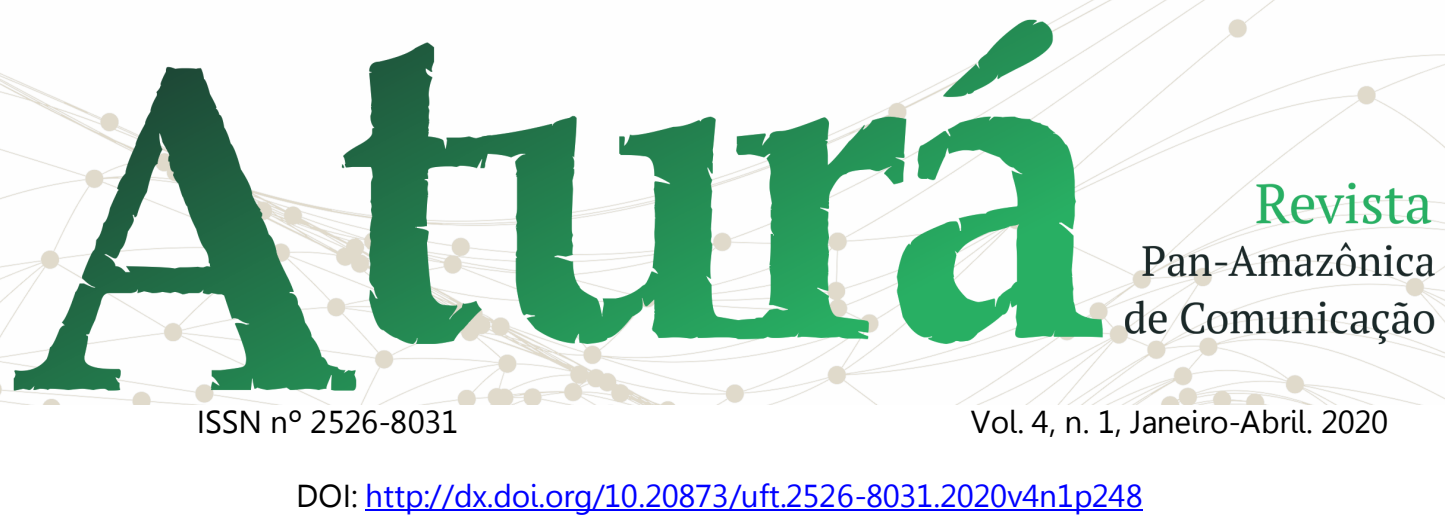

Observamos que do total de matéria enquanto as demais foram publicadas em analisadas, pouco mais $44 \%$ das notícias tiveram destaque na primeira página do jornal, páginas secundárias e editorias de alcance mais amplo.

Tabela 1 - Matérias coletadas no período analisado

\begin{tabular}{|c|c|c|}
\hline Manchete & Data & Editoria \\
\hline Número de morte por Aids em Roraima aumenta para & $27 / 07 / 199$ & Cidade \\
vinte & 3 & \\
\hline Aids & $28 / 07 / 199$ & Cidade \\
\hline Detento da penitenciária agrícola em fase terminal de & 3 & \\
\hline Vaúde vai criar código para aidéticos & $28 / 05 / 199$ & Cidade \\
& 6 & \\
\hline Começa hoje campanha de prevenção contra Aids* & $11 / 06 / 199$ & \\
& 6 & \\
\hline 17 mil pessoas podem ter contraído o vírus da Aids & $12 / 06 / 199$ & Cidade \\
& 6 & \\
\hline Vítimas de Aids esperam coquetel em Roraima & $19 / 07 / 199$ & Cidade \\
& 6 & \\
\hline Projeto obriga governo a comprar remédios anti- & $15 / 08 / 199$ & Política \\
Aids* & 6 & \\
\hline Postos para tratamento de DST são abertos no & $17 / 08 / 199$ & Cidade \\
interior* & 6 & \\
\hline Aids avança em municípios do interior & $27 / 08 / 199$ & Cidade \\
& 6 & \\
\hline
\end{tabular}




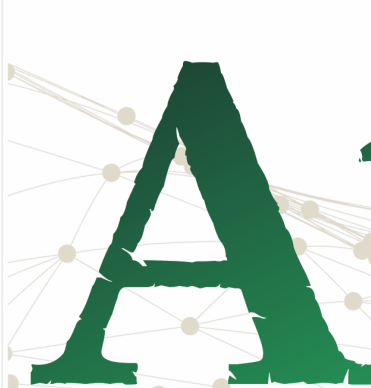

ISSN n²526-8031

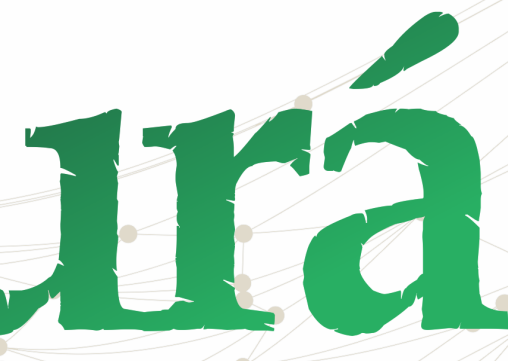

Vol. 4, n. 1, Janeiro-Abril. 2020
Revista

Pan-Amazônica

de Comunicação

DOI: http://dx.doi.org/10.20873/uft.2526-8031.2020v4n1p248

\begin{tabular}{|c|c|c|}
\hline Ministério vai distribuir AZT em xarope para crianças com AIDS* & $\begin{array}{c}13 / 09 / 199 \\
8\end{array}$ & $\begin{array}{c}\text { Variedade } \\
\text { s }\end{array}$ \\
\hline Aids aumenta em 0,1\% em mulheres* & $\begin{array}{l}17 / 09 / 199 \\
8\end{array}$ & $\begin{array}{l}2^{\circ} \\
\text { Caderno }\end{array}$ \\
\hline Campanha itinerante tenta conter avanço* & $\begin{array}{c}16 / 11 / 199 \\
8\end{array}$ & $\begin{array}{l}\text { Variedade } \\
\mathrm{s}\end{array}$ \\
\hline Mundo se une na luta contra AIDS & $\begin{array}{l}27 / 11 / 199 \\
8\end{array}$ & Cidade \\
\hline $\begin{array}{l}\text { Voluntários alertam contra o risco de contágio com o } \\
\qquad \text { HIV }\end{array}$ & $\begin{array}{l}02 / 12 / 199 \\
8\end{array}$ & Cidade \\
\hline Faltam remédio e kit para teste de HIV & $\begin{array}{c}22 / 09 / 200 \\
0\end{array}$ & Cidade \\
\hline Morre a $92^{a}$ vítima de Aids em Roraima* & $\begin{array}{c}12 / 01 / 200 \\
1\end{array}$ & Cidade \\
\hline Presidiárias fazem teste anti-HIV & $\begin{array}{c}06 / 03 / 200 \\
1\end{array}$ & Cidade \\
\hline
\end{tabular}

*Matérias que não tiveram destaque na primeira página do jornal

Do total de itens coletados 12 foram publicadas na editoria Cidade; uma em Política; uma em destaque na primeira capa da Segunda Folha; uma na Geral; e duas na editoria de Variedades. Os $67 \%$ dos itens atribuídos a editoria de Cidades se justificam pelo caráter local das notícias, característica atribuída a proximidade geográfica conforme citada por Walter Lippmann (1922) apud Silva (2005, p.101).

Apesar disso, o veículo utilizou poucas vezes palavras que remetessem a proximidade da região para relacionar ao fato, ou seja, do total de matérias coletadas, apenas três utilizaram a palavra Roraima, enquanto outra utilizou a palavra interior para se referir aos municípios do Estado ao tentar uma maior 


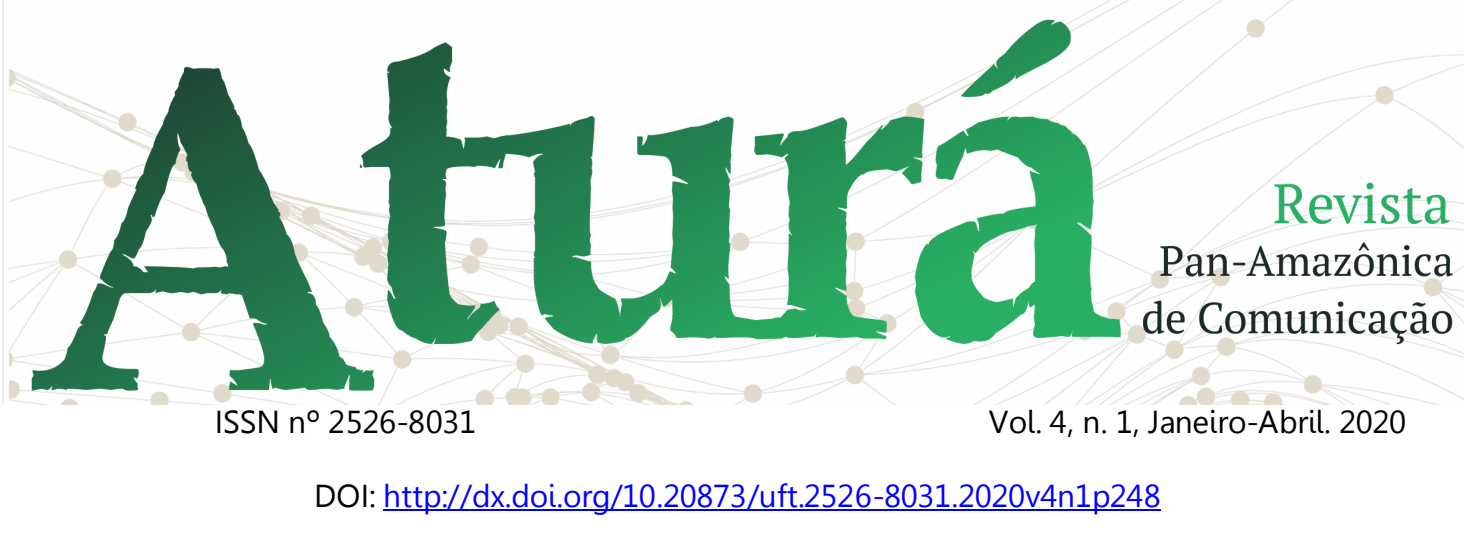

aproximação da temática. Outro texto utilizou Boa Vista em uma chamada destacada na primeira página com o mesmo propósito - a matéria: "Morre mais uma pessoa em Boa Vista", veiculada no dia 14 de julho de 1993.

Logo em seguida aparece a editoria de Variedades, com duas notícias, são elas: "Ministério vai distribuir AZT em xarope para crianças com AIDS" e "Campanha itinerante tenta conter avanço", ambas publicadas em 1998, sendo a primeira no mês de junho e a segunda somente em novembro daquela ano.

Ao mesmo tempo as editorias Geral e Política, tiverem publicadas apenas uma matéria cada, porém, ao longo da pesquisa não foi possível identificar uma das editorias, enquanto outra notícia teve destaque na Segunda Folha - o segundo caderno do jornal.

A primeira notícia encontrada sobre Aids no material analisado data de 27 de julho de 1993, sob o título "Número de morte por Aids em Roraima aumenta para vinte" (ver Figura 1). No texto o repórter noticia novas mortes causada em decorrência da Aids e novos casos da doença, tendo como fonte principal a Coordenadoria do Programa das Doenças Sexualmente Transmissíveis e Aids (DST/AIDS) da Secretaria Estadual de Saúde (Sesau) e sua responsável Madalena Menezes.

Figura 1 - Matéria publicada no Jornal Folha de Boa Vista em 27/07/1993.

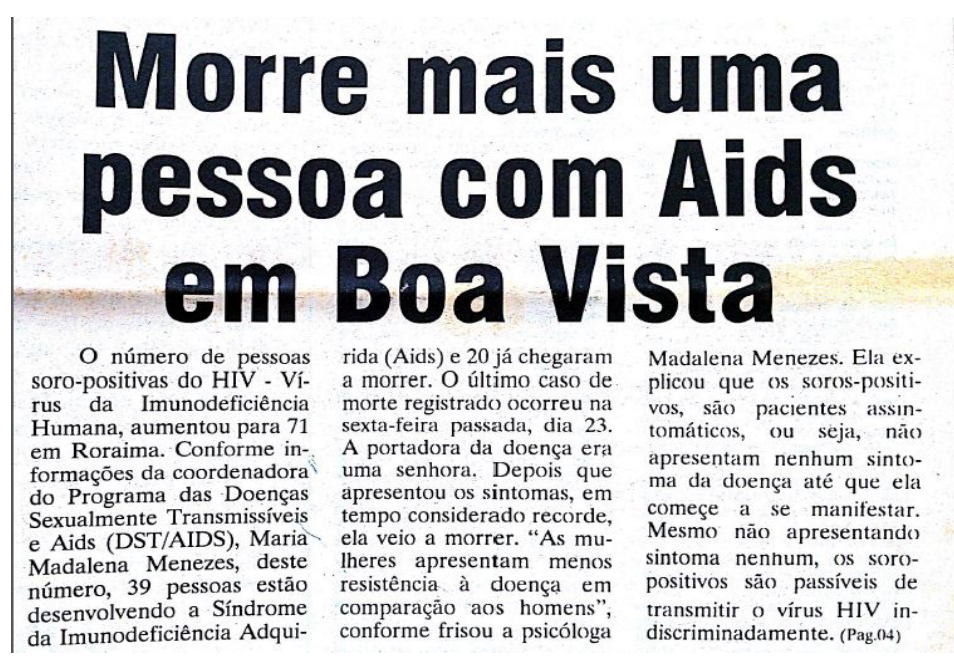




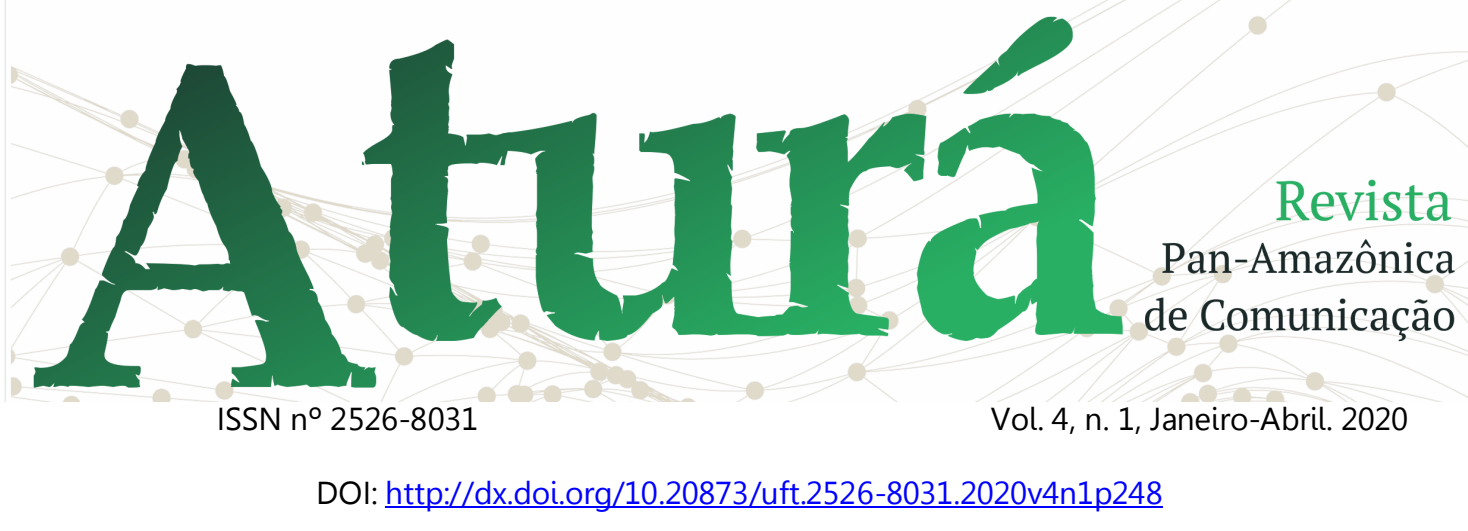

Na matéria a fonte explica que pessoas do sexo feminino apresentam menor resistência à doença se comparadas a pessoas do sexo oposto, por conta do comportamento sexual, considerado como fator de risco. $O$ repórter também apresenta dados que revelam que a incidência do HIV foi duas vezes maior entre os heterossexuais do que nos homossexuais, de acordo com dados apresentados pela própria fonte. Além disso, a reportagem apresenta dois boxes, um falando sobre as formas de prevenção da doença e outra com dados estatísticos dos casos mundo a fora.

Já na segunda matéria, publicada um dia depois, intitulada "Detento da penitenciária agrícola em fase terminal de Aids", o repórter relata a história do primeiro reeducando portador do vírus em um presídio de Roraima, após ser infectado ao manter relações sexuais com uma norte-americana. A matéria tem como fonte principal a médica infectologista Waldemariza Gomes.

A reportagem também apresenta dois boxes, num deles, o portador da doença faz

uma alerta para as outras pessoas, para que elas tomem cuidado ao manter relações sexuais e usem camisinha. Neste caso observamos que ideia de fazer um jornalismo humanizado, no qual a pessoa infectada é agente ativa da notícia, já era praticado naquela época pelo jornal Folha de Boa Vista. Ou seja, além da especialista, o veículo dá voz ao paciente para que ele também seja ouvido por outras pessoas a fim de que elas saibam a realidade sobre a Aids.

$\mathrm{Na}$ análise detalhada destas duas matérias jornalísticas e na sua correlação com os demais textos selecionados no corpus pudemos observar que ambas utilizam palavras em comum e de destaque, que aparecem repetidas vezes ao longo do texto e que merecem ser estudadas.

Partindo para uma análise mais quantitativa podemos observar que as palavras mais utilizada pelos repórteres são Aids e Doença(s). Na matéria do dia 27 de julho de 1993, a palavra Aids é repetida 20 vezes, enquanto a notícia do dia seguinte aparece apenas cinco. Já Doença(s) aparece 


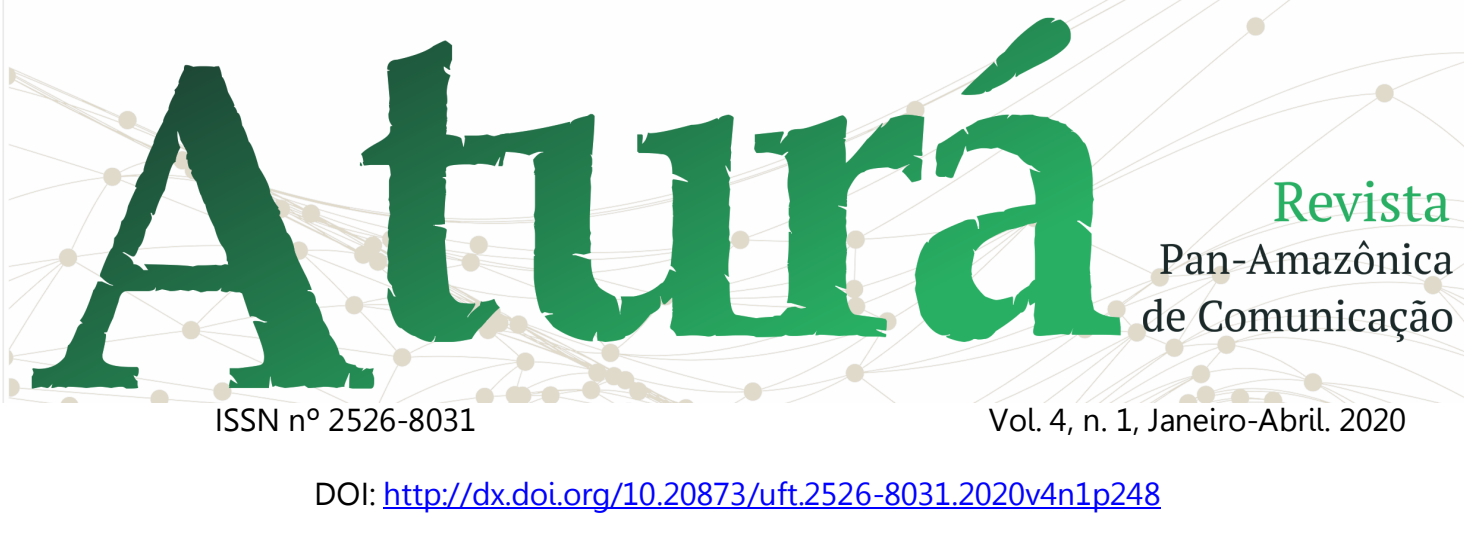

logo em seguida com 16 repetições na primeira e sete na segunda.

Também podemos observar que a palavra Vírus vem geralmente grafada juntamente com HIV. Além disso, os jornalista abusam dos sinônimos para se referir a pessoa infectada com o vírus. As palavras variam entre, Paciente, Portador, Soropositivo e Aidético - termo considerado pejorativo, uma vez que faz referência às pessoas já em estado avançado da doença. Aidético foi o termo que apareceu o maior número de vezes no material, juntamente com a palavra Paciente.

Conforme Kucinski (2000, p.184) na cobertura da Aids novos estereótipos foram criados e estereótipos antigos reforçados em abordagens que se revelaram equivocadas, centradas em "grupos de risco", inspiradas em visões moralistas ou religiosas do mundo, e não em conceitos epidemiológicos. Essa linha de discussão fica evidenciada e é corroborada pela material publicado pelo Jornal Folha de Boa Vista sobre a doença.

A palavra Aids aparece ainda em 13 manchetes entre 18 matérias coletadas durante a pesquisa. Enquanto isso, a palavra
HIV aparece uma única vez. Dessa forma, percebemos que o veículos e utiliza de termos sensacionalistas e trata suas notícias com apelo emocional para o convencimento do leitor. Conforme Almeida (2008, p.59) "[...] o uso excessivo de adjetivos - embora estes não sejam aceitos em um Jornalismo que prega a objetividade -, de hipérboles e metáforas são exemplos das estratégias utilizadas pelo sensacionalismo".

Três anos mais tarde, em 1996, o jornal volta a veicular notícias com a temática HIV/Aids no dia 18 de maio - sendo a mesma edição para os dias 19 e 20 referente ao sábado e domingo, respectivamente. $\mathrm{Na}$ primeira página do jornal a notícia recebe a seguinte chamada: "Saúde quer eliminar preconceitos a aidéticos", enquanto na matéria propriamente dita ela recebe o título: "Saúde vai criar código para aidéticos".

Logo, percebemos que a substituição de palavras que num primeiro momento pode confundir o leitor obrigando-o a ler todo o texto para compreender do que realmente se trata. Essa talvez seja uma tática para prender a atenção dele. 


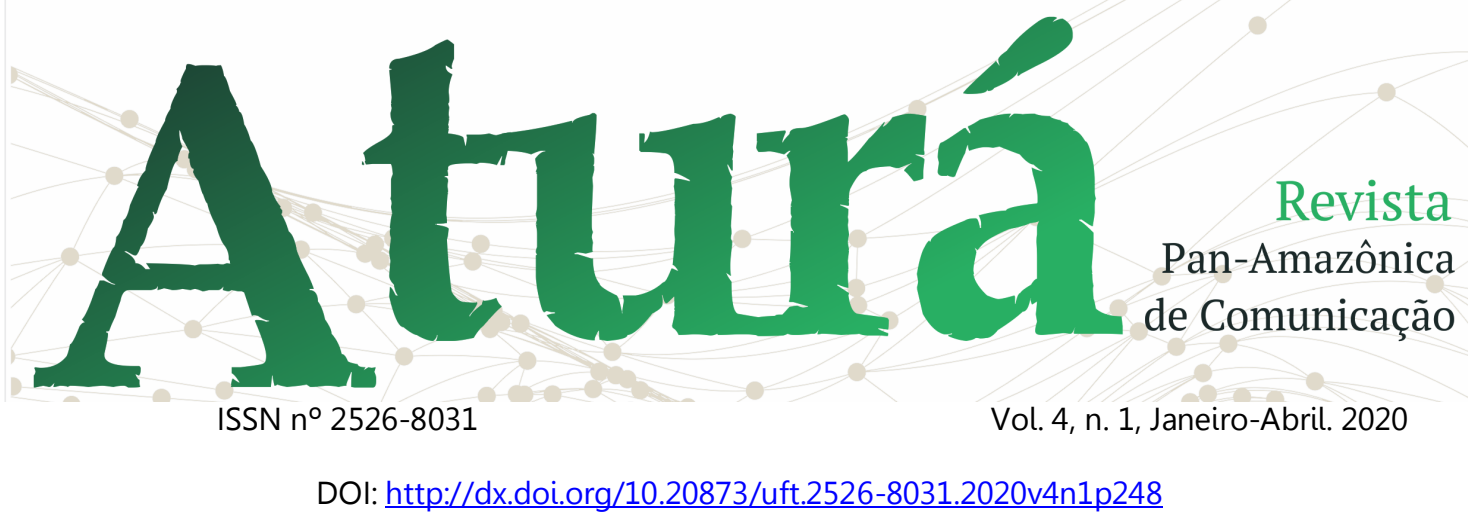

Ao longo da matéria, o repórter explica de que forma o Ministério da Saúde busca amenizar 0 preconceito contra os soropositivos por meio da elaboração de um relatório sobre dados da doença para a possível implantação de uma Rede Nacional de Direitos Humanos. E, mais uma vez, a diretora da Coordenadoria do Programa DST/AIDS, da Secretaria Estadual de Saúde (Sesau), Madalena Menezes volta a ser a fonte principal da notícia.

No mês seguinte a Folha de Boa Vista menciona a palavra Aids uma única vez na matéria "Vigilância Sanitária vai multar hospitais", publicada no dia 6 de junho de 1996 na editoria Geral, para se referir ao risco de contaminação da doença através do lixo hospitalar. Cinco dias depois, no dia 11 de junho de 1996, o jornal divulga uma notícia sobre uma campanha de prevenção contra a Aids e mais uma vez Madalena Menezes volta a aparecer como fonte.

No dia 12 daquele mesmo mês, Madalena Menezes aparece na página 15 do jornal, na editoria de Cidades, informando que 17 mil pessoas podem ter contraído o vírus da
Aids em Roraima, conforme dados da Organização Mundial de Saúde (OMS). Na matéria, o repórter ressaltou a realização da campanha de prevenção DST/Aids, publicada no dia anterior.

No ano em que o Governo Federal fixa o direito ao recebimento de medicação gratuita para tratamento da doença, em 1996, a Folha de Boa Vista publica no dia 19 de julho, também na editoria de Cidade a seguinte notícia: "Vítimas da Aids esperam coquetel em RR", na qual revela a expectativa dos soropositivos em receber o medicamento. No texto, a médica infectologista Waldemariza Gomes explica os efeitos do uso do coquetel pelas pessoas que vivem com HIV.

Quase um mês mais tarde, o deputado Hélder Grossi apresenta um projeta na Assembleia Legislativa de Roraima que obriga - Governo do Estado a fornecer medicamentos a todas as pessoas infectadas com HIV, conforme notícia publicada na editoria de Política da Folha de Boa Vista no dia 15 de agosto de 1996, sob o título "Projeto obriga governo a comprar remédios antiAids". 


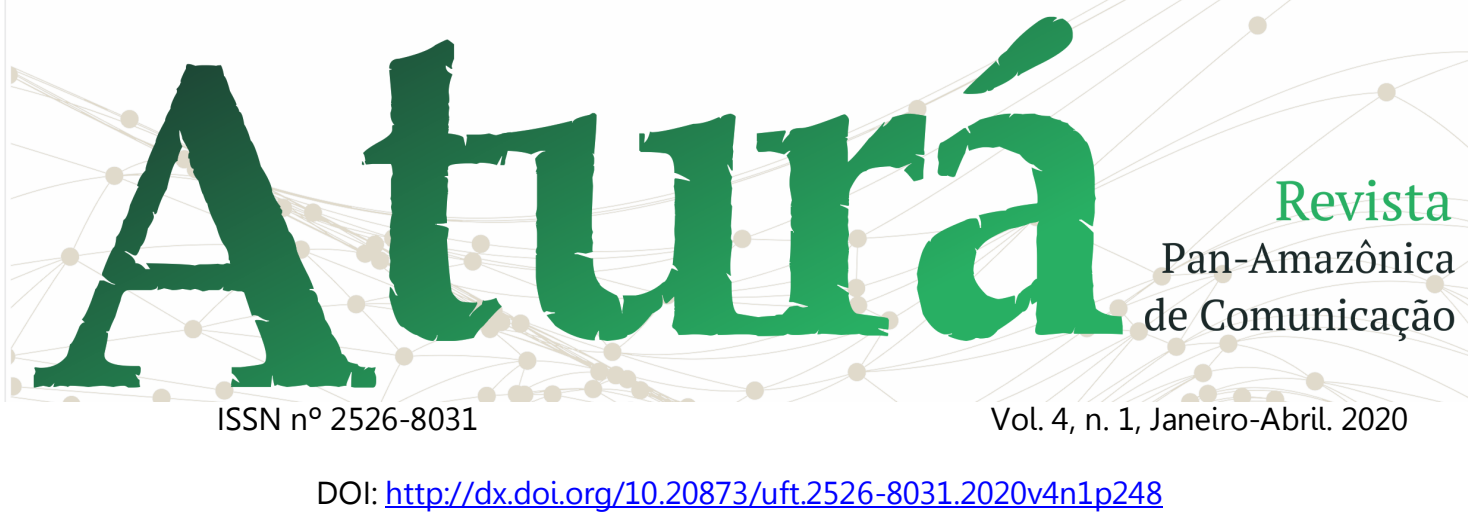

Dois dias, depois o jornal informa que "Postos para tratamento de DST são abertos no interior". Na reportagem Madalena Menezes fala sobre a instalação de novos Centros de Tratamento e prevenção de DST em quatro municípios do interior de Roraima.

Dez dias depois, como resultado a implantação dos Centros de Tratamento, Madalena pôde constatar um crescimento da doença nos municípios do interior do Estado. No decorrer do texto ela volta a ressaltar a incidência de casos em heterossexuais, desmistificando o boato da doença estar relacionada aos homens gays.

A partir disso, notamos que das oito matérias publicadas em 1996, apenas metade dela tiveram destaque na primeira página do Jornal Folha de Boa Vista, enquanto as outras notícias receberam uma atenção menor, possivelmente pelo contexto macro dado ao assunto, quando poderiam ter tido a mesma atenção especial que as demais, já que algumas delas davam continuidade a outra notícias já publicadas pelo veículo.

Com relação as fontes de informações utilizadas para a construção das notícias podemos notar que Madalena Menezes, da Coordenadoria do Programa DST/AIDS, da Secretaria Estadual de Saúde (Sesau), aparece em seis das oito matérias publicadas naquele ano. Enquanto isso a figura do médio aparece uma única vez.

$O$ veículo utiliza apenas uma fonte ao invés de buscar outros dados ao noticiar o fato, ficando limitado apenas a uma fonte oficial, quando poderia também obter informações por meio de organizações não governamentais ou associações de pessoas portadoras do vírus, o que reitera a afirmação de Lopes et al. (2011, p.103), na qual as fontes de informação solicitadas para falar na matéria deste gênero são em geral oficiais, pois segundo as autoras, esta fontes encontram na mídia um meio de difusão de informação e criação de sentido, de diferentes formas, quer seja informativo, educacional, ou até persuasivo, com o objetivo de promover a compreensão aos assuntos relacionados à saúde.

Conforme nossa pesquisa, o Jornal Folha de Boa Vista só retoma a temática dois anos depois, em 1998 com a seguinte notícia: 


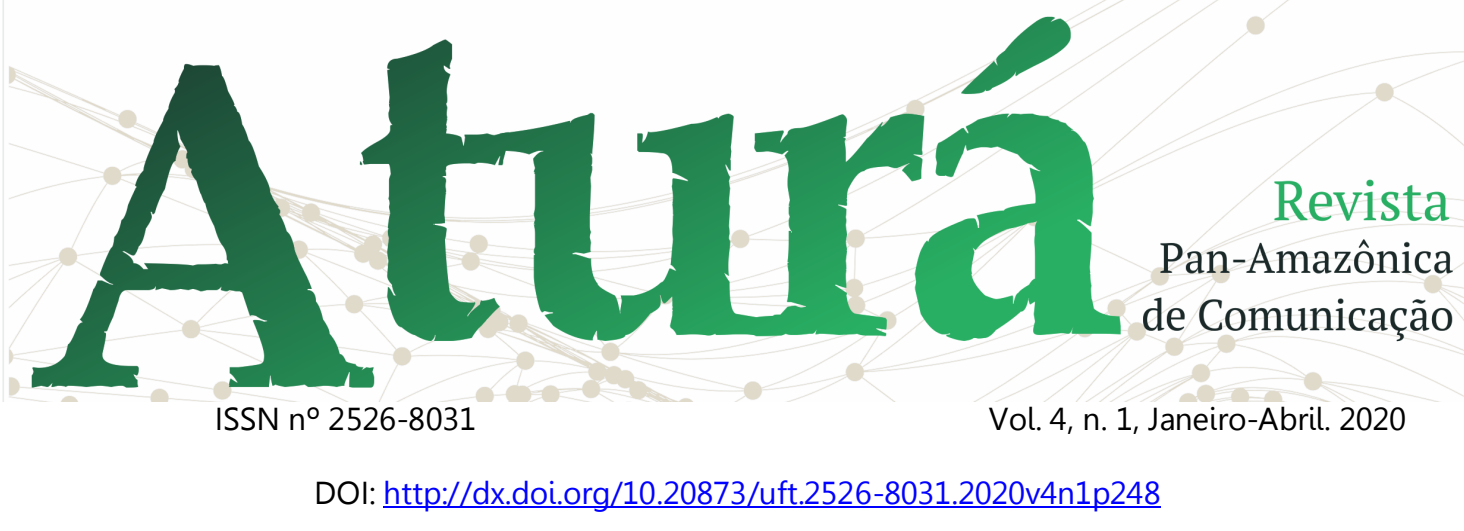

"Ministério vai distribuir AZT em xarope para crianças com Aids", publicada no dia 13 de setembro na editoria de Variedades. Nessa edição podemos observar que após cinco anos noticiando sobre a Aids, o jornal divulga uma notícia de abrangência nacional mediante aproveitamento de release oriundo do Ministério da Saúde.

Quatro dias depois, em 17 de setembro de 1998, o Jornal volta a publicar notícia de cunho nacional, desta vez sobre o aumento dos casos de Aids entre mulheres, conforme a agência de notícia AJB de Brasília, sendo um dos destaques da primeira página do Segundo Caderno.

No dia 16 de novembro do mesmo ano, o veículo volta a abordar o contexto regional por meio da matéria "Campanha itinerante tenta conter avanço", publicada também na editoria Variedades. A reportagem inclui dois boxes. No primeiro o jornalista informa que as mulheres são as mais interessadas e fazer teste para a identificação de DST, enquanto no segundo informa sobre os serviços do Centro de Testagem e Aconselhamento (COA). A notícia tem como fonte a coordenadora do COA Wlderly Jeanne.

No dia 27 do mesmo mês, Madalena Menezes, coordenadora do Programa DST/AIDS da Sesau, retoma a temática para promover uma campanha de combate à doença no dia $1^{\circ}$ de dezembro (Dia Mundial de Combate a Aids), conforme a matéria publicada na Folha de Boa Vista, na editoria de Cidade. Esta é a primeira matéria de destaque que tematiza a Aids naquele ano.

Um dia após o lançamento da campanha de $1^{\circ}$ de dezembro, noticiada no dia 27 de novembro, pudemos notar que o jornal fez a cobertura do evento e detalhou o ocorrido na quinta página do jornal sob o título "Voluntários alertam contra risco de contágio com HIV", na editoria de Cidade.

Logo, das cinco matérias publicadas em 1998, apenas duas tiveram destaquem. Desse total, duas apresentaram conteúdo mais amplo de âmbito nacional, enquanto as demais trataram as demandas locais, seguindo o valor notícia de aproximação geográfica já falado anteriormente. 


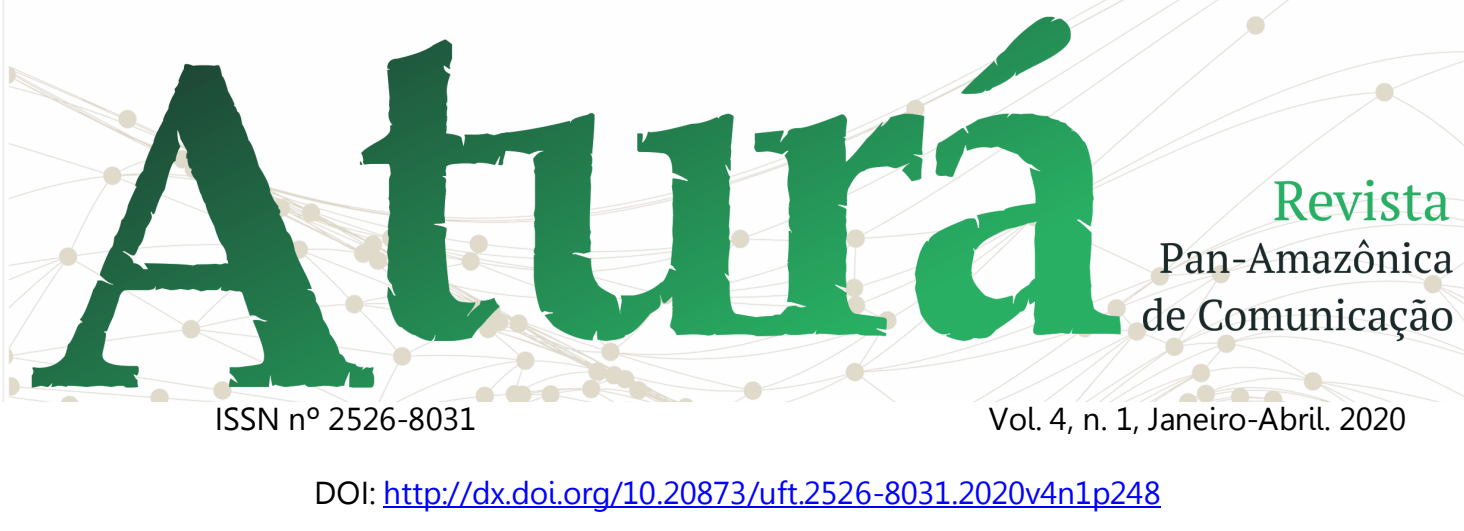

No ano de 2000 foi possível encontrar apenas uma notícia publicada na Folha, sendo ela datada do dia 22 de setembro, falando sobre a falta de remédio para realização do teste de HIV. Diferente das notícias anteriores, a reportagem traz uma nova fonte, a Associação de Luta pela Vida (ALV). Outra novidade é a assinatura do repórter, algo que não era identificada nas edições anteriores analisadas. Vale lembrar que a notícia foi destaque na edição do jornal daquele ano.

Já, no dia 12 de janeiro de 200, o jornal publica a seguinte notícia: "Morre $92^{\mathrm{a}}$ vítima de Aids em Roraima", na editora de Cidade. $\mathrm{Na}$ ocasião, o repórter Alexandre Dourado narra a denúncia do presidente da Associação de Luta pela Vida, José Santo, na qual ele fala que a morte foi causada pela falta de assistência especializada. Notamos que o gênero aparece pela primeira vez desde 1993. Apesar de relevante, a notícia não teve desta na primeira página.

Mais tarde, do dia 8 de março do mesmo ano, o jornal retoma a temática da Aids dentro de presídios, na matéria intitulada "Presidiárias fazem teste anti-HIV". No texto, a repórter Tânia Gadelha fala sobre uma ação do Centro de Tratamento e Aconselhamento realizado dentro da Penitenciária Agrícola de monte Cristo na ala desistida às mulheres.

Entre anos de 2000 e 2001 pudemos notar que a Folha de Boa Vista passou a adotar a assinatura dos repórteres que redigiam as notícias, além disso buscaram fontes alternativas que pudesse falar sobre o tema, mantendo o assunto em pauta em âmbito regional, mesmo que as aparições do tema tenham se mantido esporádicas no periódico.

\section{Considerações Finais}

Como foi observado ao longo deste trabalho, os meios de comunicação foram a primeira resposta para os questionamentos acerca do HIV/Aids. Foi a mídia a responsável por traduzir os dados científicos apontados por médicos e especialista, para que a sociedade pudesse compreender melhor as informações sobre o vírus. Além disso, a mídia foi responsável construção da imagem da doença e contribui ainda hoje para causar 


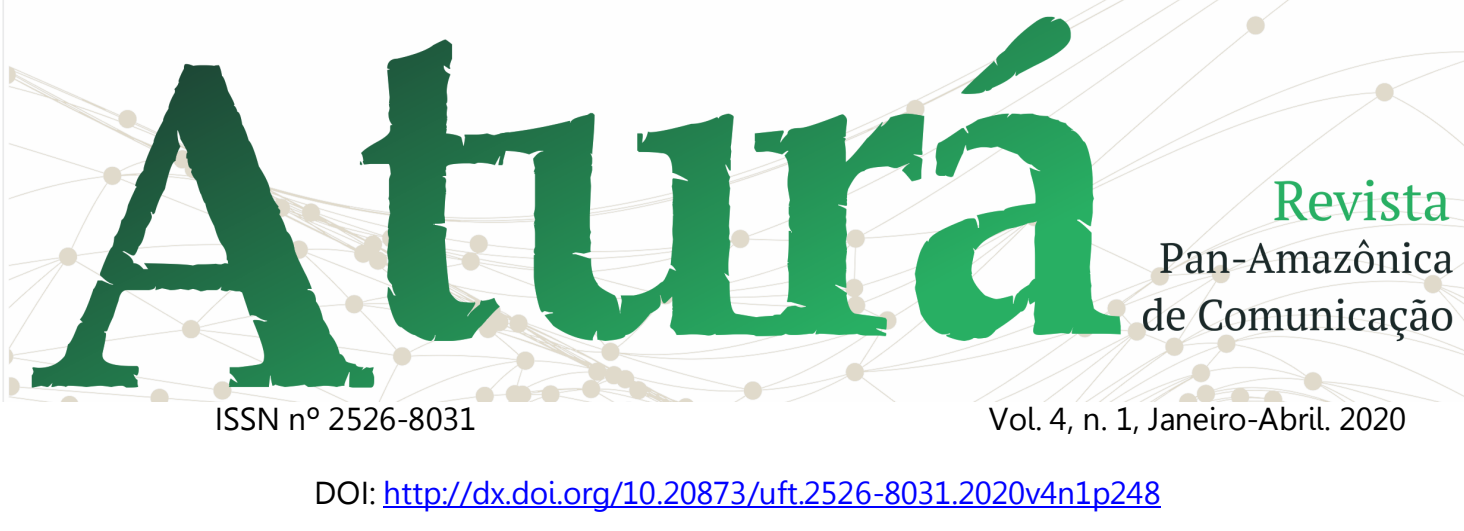

muito preconceito quando o assunto vem à tona.

soropositivas, 570 delas eram héteros e 264 homossexuais.

Ao longo dos mais de 30 anos desde a

A escassez de fontes não foi um aparição da doença, vimoso surgimento das hipóteses sobre um possível "câncer gay" ou "praga rosa" - termos criados para se referir a doença como sendo exclusiva dos homossexuais. Mas também, durante este mesmo período, vimos estes termos caírem em desuso mesmo que o preconceito ainda exista.

O Jornal Folha de Boa Vista, por exemplo, mesmo não utilizando os termos citados acima, também reproduziu os mesmos pré-conceitos e erros cometidos pela imprensa nacional, como o uso da palavra aidéticos.

Os textos jornalísticos publicados entre 1993 e 2001 revelaram que não é somente a população gay a ser afetada pela doença, mas que ela pode atingir pessoas de diferentes idades e sexos, como revelam os dados do Sistema Nacional de Agravos e Notificação (Sinan-net). Em janeiro de 2018, por exemplo, das 1065 pessoas diagnosticadas como problema para o veículo que soube abordar o assunto de diferentes maneiras: dentro de presídios, campanhas e denúncias. Quanto as campanha preventivas, percebemos que 0 jornal veiculou uma única vez a temática, em data alusiva, ao contrário do senso comum jornalístico que prega que a pauta sobre esse tema segue um calendário pré-elaborado para ser noticiado.

Vale lembrar que o jornalista não foi único responsável pelas informações transmitidas sobre a Aids nos primeiros anos, pois na maior parte das vezes os médicos repassaram informações incompletas sobre uma doença ainda em fase de investigação. Logo, duas categorias consideradas de credibilidade pela sociedade, transmitiam não só fatos equivocados, mas também preconceitos que permanecem até os dias atuais.

O jornalista enquanto comunicador social também deve agir como um cidadão e tem a obrigação de seguir os códigos de ética 


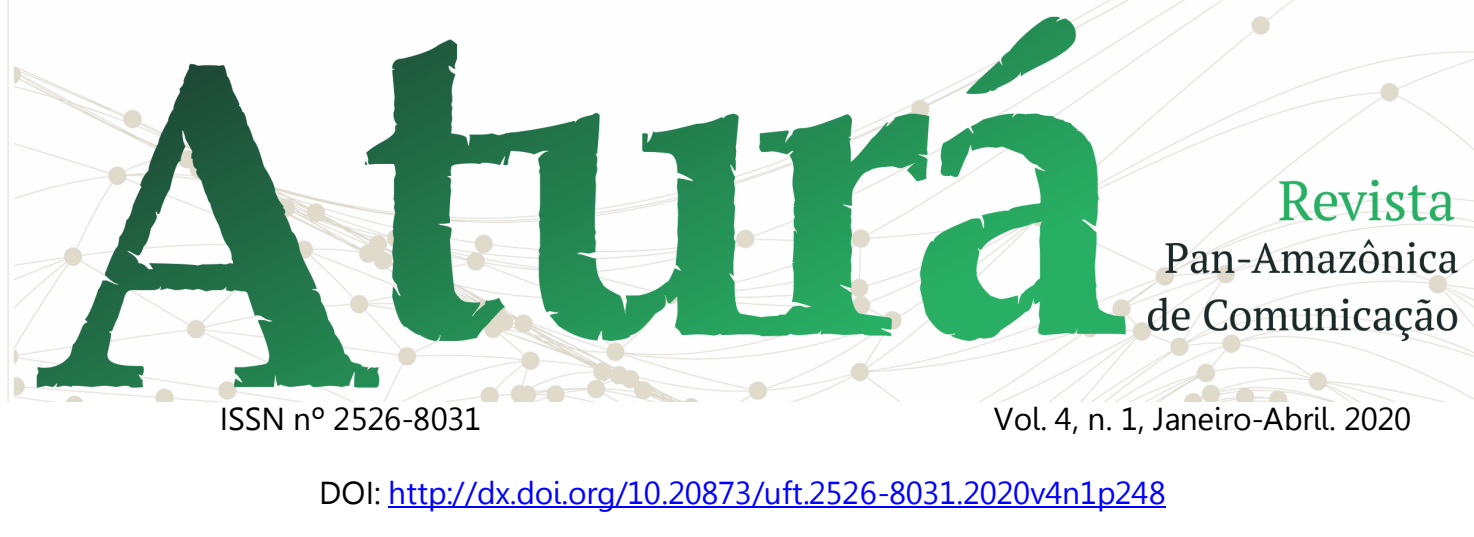

correspondentes da profissão para que os princípios básicos da busca pela imparcialidade e a objetividade ocupem o espaço do sensacionalismo, que por vezes pode comprometer a veracidade do fato.

Durante o período estudado, a situação de incerteza, as dificuldades biológicas e sociais em que viviam os soropositivos os tornavam protagonistas perfeitos para reportagens sensacionalistas. Este, aliás, é um dos principais desafios éticos enfrentados pelo jornalismo - trabalhar o respeito, a dignidade e os direitos dos portadores do HIV.

Nossa ideia aqui foi, portanto, analisar a cobertura do jornal Folha de Boa Vista sobre o tema HIV/Aids, apontar suas recorrências mas também suas lacunas, a fim de fazer com o que o jornalista desperte o interesse por esta temática e siga seus princípios éticos, pois cabe a ele decidir como contar as histórias destes HIV positivos: se de forma humana, solidária e sem dramatizá-la excessivamente ou recheada de clichês e preconceitos.

As pessoas vivendo com HIV prestam um serviço ao jornalismo de saúde quando se propõe a contar sua história, portanto devemos respeitá-las enquanto cidadãos e enquanto fontes que dispõe de seu tempo para relatar uma história.

\section{REFERÊNCIAS}

ALMEIDA, Marília. O percurso da mídia na Aids: análise da cobertura do jornal "O Popular" de 1983 a 2007. Disponível em: https://repositorio.bc.ufg.br/bitstream/ri/4389 /5/TCCG\%20-\%20Jornalismo\%20-

\%20Mar\%C3\%ADlia\%20Almeida.pdf. Acesso em: 5 fev. 2017.

ALVES, M. R. DE A. B.; CARDOSO, J. M. Publicidade governamental de utilidade pública em saúde: considerações sobre a dimensão organizacional no circuito das práticas de produção no Ministério da Saúde. Revista Observatório, v. 3, n. 1, p. 415433, 30 mar. 2017.

BAPTAGLIN, L. A.; CHIERENTIN SANTI, V. J. As intervenções artísticas urbanas no circuito da arte em Roraima e o potencial comunicativo dos saberes artísticos amazônicos. Revista Observatório, v. 4, n. 4, p. 615-637, 29 jun. 2018.

CEZARI, E. J.; PEREIRA, R. T. Educação em saúde na educação infantil: o contexto da prática docente. Revista Observatório, v. 3, n. 3, p. 561-583, 1 maio 2017.

DEFOE, Daniel. Diario del año de la peste. Oveja Negra, 1985. Disponível em: http://s3.amazonaws.com/academia.edu.docu ments/32560217/Daniel_Defoe__Diario_del_ano_de_la_peste.pdf?AWSAccessK eyld=AKIAIWOWYYGZ2Y53UL3A\&Expires $=14$ 


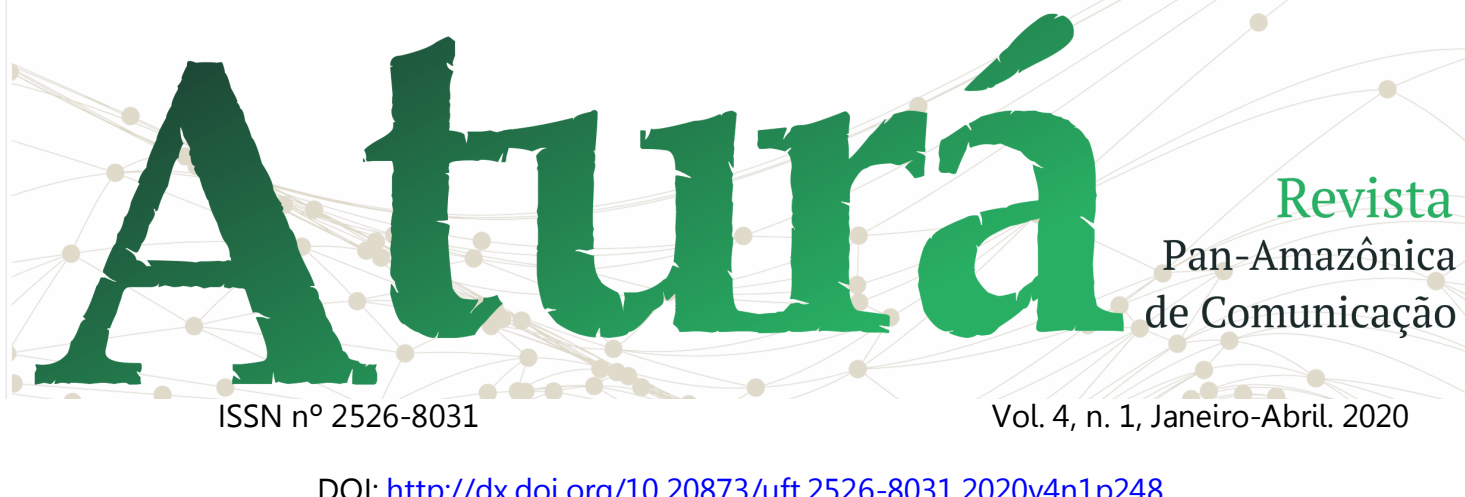

DOI: http://dx.doi.org/10.20873/uft.2526-8031.2020v4n1p248

88918913\&Signature $=$ OlWbzc7mUelUHMAM AtT7CtwZJXc\%3D\&response-contentdisposition=inline\%3B\%20filename\%3DDanie l_Dafoe_Diario_del_ano_de_la_peste.pdf.

Acesso em: 27 fev. 2017.

KUCINSKI, Bernardo. Jornalismo, saúde e cidadania . Disponível em: http://www.scielo.br/pdf/icse/v4n6/25.pdf. Acesso em: 27 fev. 2017.

LOPES et al. Jornalismo de saúde e fontes de informação, uma análise dos jornais portugueses entre 2008 e 2010. Disponível em: http://repositorium.sdum.uminho.pt/handle/1 822/29438. Acesso em: 31 jan.2017.

MACEDO, Mônica et al. Divulgação de saúde na imprensa brasileira: expectativas e ações concretas. Disponível em: http://www.jornalismocientifico.com.br/jornali smocientifico/artigos/jornalismo_saude/artig o5.php. Acesso em: 1 fev. 2017.

MACHADO, L. S.; COSTA, T. K. DE L.; MORAES, R. M. DE. Multidisciplinaridade e $O$ desenvolvimento de serious games e simuladores para educação em saúde. Revista Observatório, v. 4, n. 4, p. 149-172, 29 jun. 2018.

MIRANDA, C. G. L.; CASTRO, M. S.; SOARESSOBRINHO, J. L. Construção compartilhada de vídeo para educação de idosos hipertensoS. Revista Observatório, v. 5, n. 6, p. 933-948, 1 out. 2019.

MORAIS, Vângela M. I. de. A mídia impressa local: uma agenda de constrangimentos e motivações. Comunicação \& Sociedade. Disponível em: www.metodista.br/revistas/revistasims/index.php/CSO/article/view/3983. Acesso em: 1 fev. 2017.

OLIVEIRA, G. M.; SANTOS, L. F. Uso de aplicativos para dispositivos móveis no processo de educação em saúde: reflexos da contemporaneidade. Revista Observatório, v. 4, n. 6, p. 826-844, 8 out. 2018.

SEIXAS, L. Valores notícia: uma proposta de análise. Revista Observatório, v. 4, n. 4, p. 334366, 29 jun. 2018.

SILVA, Gislene. Para pensar critérios de noticiabilidade. Disponível em: https://periodicos.ufsc.br/index.php/jornalism o/article/viewFile/2091/1830. Acesso em: 8 nov. 2016.

SILVA, Gislene. A ENGRENAGEM DA NOTICIABILIDADE NO MEIO DO REDEMOINHO. Revista Observatório, v. 4, n. 4, p. 308-333, 29 jun. 2018.

SILVA, P. S. R.; VIEIRA, J. G. Uma breve análise histórica do jornal Folha de Boa Vista e suas influências políticas e ideológicas. Disponível em:

http://wilikit.ifrr.edu.br/SISTEMAS/revista/inde x.php/revista/article/view/103/97. Acesso em:1 fev. 2017.

SISTEMA NACIONAL DE AGRAVOS E NOTIFICAÇÃO (SINAN-NET). Investigação de Aids adulto. Secretaria de Estado da Saúde de Roraima (Sesau). Boa Vista. 2018. 